\title{
Pengaruh Blended Learning Berbasis Edmodo dan Motivasi Belajar Terhadap Hasil Belajar IPA Biologi dan Retensi Siswa pada Sistem Peredaran Darah Manusia di Kelas VIII SMP Negeri 5 Medan
}

\author{
Utami Alam Daulay, Syarifuddin, Binari Manurung \\ Program Studi Pendidikan Biologi Pascasarjana, Universitas Negeri Medan
}

\begin{abstract}
The research was aim to know: (1) influence of blended learning based edmodo on learning outcome; (2) influence of blended learning based edmodo on retention; (3) influence of motivation on learning outcome; (4) influence of motivation on retention; (5) interaction between blended learning based edmodo and motivation on learning outcome; (6) interaction of blended learning based edmodo and motivation on retention in grade VIII at SMP N 5 Medan. The research was quasy experiment. The analyze data technique were using ANAVA two ways with significance 0.05 . the result revealed that: (1) there was influence of blended learning based edmodo on learning outcome $(\mathrm{F}=86.668 ; \mathrm{P}=$ $0.000)$; (2) there was influence of blended learning based edmodo on retention $(\mathrm{F}=35.476 ; \mathrm{P}=$ $0.000)$; (3) there was influence motivation on learning outcome $(\mathrm{F}=37.597 ; \mathrm{P}=0.000)$; (4) there was motivation on retention $(\mathrm{F}=13.004 ; \mathrm{P}=0.000)$; (5) there was interaction of blended learning based edmodo and motivation on learning outcome $(\mathrm{F}=4.942 ; \mathrm{P}=0.003)$ and $(6)$ there was interaction of blended learning based edmodo and motivation on retention in grade VIII in SMP N 5 Medan $(\mathrm{F}=$ 2.946; $\mathrm{P}=0.031$ ).
\end{abstract}

Keywords: Model of Blended Learning, Edmodo, Motivation, Retention, and Learning Outcome

\section{PENDAHULUAN}

Saat ini jumlah pengguna internet di Indonesia mencapai angka 88,1 juta dan $87 \%$ diantaranya menggunakan internet dengan alasan utama untuk mengakses jejaring sosial, seperti facebook, twitter maupun instagram (data Puskakom UI). Dari banyaknya pengguna internet di Indonesia, hampir setengahnya adalah remaja yang merupakan usia pelajar. Tingginya partisipasi pelajar dalam menyumbang jumlah pengguna internet di Indonesia disebabkan karena kemudahan mendapatkan fasilitas internet melalui berbagai perangkat, baik telepon genggam, smartphone, laptop maupun tablet.

Berdasarkan observasi yang dilakukan peneliti kepada siswa kelas VIII di SMP N 5 Medan diperoleh bahwa hampir setiap hari sebagian besar siswanya mengakses aplikasi media sosial seperti facebook untuk menghabiskan waktu luang mereka, baik melalui telepon genggam, smartphone, laptop maupun tablet. Padahal jejaring sosial seperti facebook dapat digunakan sebagai media pembelajaran dimana siswa dapat berdiskusi mengenai tugas, materi pelajaran dengan sesama teman bahkan dengan guru.Selain itu pembelajaran biologi yang berlangsung di SMP N 5 Medan masih menggunakan metode ceramah dengan papan tulis sebagai media pembelajaran.Seharusnya, belajar tidak cukup hanya dengan mendengar dan melihat tetapi harus melakukan aktivitas lain seperti membaca, bertanya, menjawab, berpendapat, mengkomunikasikan, diskusi dan memanfaatkan peralatan, dengan melakukan aktivitas seperti itu, siswa dapat mempunyai retensi belajar yang baik. Pembelajaran cenderung monoton dan kurang menyenangkan,pada akhirnya berdampak pada motivasi belajar siswa.Jika siswa tidak termotivasi tentunya kegiatan pembelajaran tidak berhasil dan hasil belajar siswa pun kurang memuaskan.

Selain itu mata pelajaran Ilmu Pengetahuan Alam yang diberlakukan di SMP Negeri 5 Medan memiliki materi pelajaran terpadu.Artinya, materi yang diajarkan kepada siswa mencakup pelajaran biologi, fisika dan kimia.Namun waktu pembelajaran tatap muka di sekolah tidak cukup untuk mengajarkan semua materi IPA terpadu. Ini sesuai dengan hasil wawancara yang dilakukan peneliti kepada guru IPA di SMP N 5 Medan, yaitu ibu Tri Handani bahwa banyak waktu pembelajaran 
tatap muka yang terpotong karena adanya libur peringatan hari besar, ujian bulanan dan ujian sekolah serta agenda kegiatan sekolah lainnya yang memotong jam pelajaran tatap muka di kelas. Sehingga materi pembelajaran yang seharusnya disampaikan menjadi tidak terlaksana.

Untuk mengatasi permasalahan di atas, maka guru dapat melakukan pembelajaran dengan menggunakan model Blended learning. Blended learning adalah suatu model pembelajaran yang menggabungkan pembelajaran tatap muka dengan pembelajaran yang menggunakan sumber belajar online.Dalam proses pembelajaran, Blended learning memerlukan media yang sesuai. Salah satu media yang sesuai dengan Blended learning adalah jejaring sosial, seperti edmodo. Menurut Zwang (2010), "edmodo adalah sebuah situs pendidikan berbasis social networking yang di dalamnya terdapat berbagai konten untuk pendidikan". Guru dapat memposting bahan-bahan pembelajaran, berbagi link dan video, penugasan proyek, dan pemberitahuan nilai siswa secara langsung.

Dengan menggunakan jejaring sosial dalam Blended learning maka siswa dapat mengulang kembali materi pembelajarannya sehingga siswa lebih memahami materi pelajarannya. Selain itu siswa lebih termotivasi belajarnya karena siswa dapat berdiskusi dengan temannya maupun dengan gurunya tentang materi pelajaran.Motivasi merupakan faktor penting dalam keberhasilan akademik. Ketika siswa termotivasi untuk belajar, prestasi akademik akan meningkat secara signifikan. Hal ini sesuai dengan hasil penelitian yang dilakukan oleh Ari Sudibjo (2013)bahwa "respons motivasi siswa terhadap penggunaan edmodo sangat kuat dan hasil belajar siswa setelah menggunakan edmodo meningkat". Hasil penelitian Herliana (2015) menyimpulkan "terdapat interaksi antara model pembelajaran Blended learning dan motivasi belajar terhadap hasil belajar fisika". Siswa yang memiliki motivasi belajar tinggi maka hasil belajar fisika dengan model Blended learning lebih tinggi dibandingkan pembelajaran langsung.
Berdasarkan latar belakang masalah diatas, maka perlu dilakukan penelitian tentang "Pengaruh Blended learning Berbasis Edmodo dan Motivasi Belajar Terhadap Hasil Belajar IPA Biologi dan Retensi Siswa Pada Sistem Peredaran Darah Manusia di Kelas VIII SMP N 5 Medan”.

\section{METODE PENELITIAN}

Penelitian ini dilakukan di SMP Negeri 5 Medan pada kelas VIII semester genap tahun pembelajaran 2015/2016. Waktu penelitian dilakukan pada bulan JanuariMaret 2016.Populasi dalam penelitian ini adalah seluruh siswa kelas VIII SMP Negeri 5 Medan Tahun Pembelajaran 2015/2016 yang terdiri dari 9 kelas. Pengambilan sampel diambil dengan teknik cluster random sampling (sampel acak berkelompok).Setelah dilakukan teknik cluster random sampling (sampel acak berkelompok) di dapat 2 kelas yang digunakan dalam penelitian yaitu kelas $\mathrm{VIII}_{5}$ dan kelasVIII 6 yang berjumlah 68 siswa.Metode yang digunakan dalam penelitian ini adalah quasi eksperiment dengan desain Treatment by Level $2 \times 2$. Penelitian ini diberikan perlakuan sebanyak 4 (empat) kali pertemuan.Perlakuan yang diberikan kepada kedua kelompok berbeda, dimana kelompok pertama yaitu kelas $\mathrm{VIII}_{5}$ menggunakan model pembelajaran Blended Learning berbasis Edmodo dan kelompok kedua yaitu kelas $\mathrm{VIII}_{6}$ menggunakan model pembelajaran langsung. Kedua kelompok tersebut diberikan tes awal (pretest) dan tes motivasi belajar pada awal perlakuan. Kemudian seluruh kelompok diberikan post test untuk mengukur hasil belajar ipa biologi dan menguji pengaruhnya pada setiap kelompok. Setelah 21 hari kedua kelompok diberikan tes kembali untuk mengukur retensi siswa.

Instrumen dalam pengumpulan data motivasi belajar siswa adalah angket yang menggunakan skala likert dalam pengukurannya dengan skala 1 sampai 5.Jumlah instrumen soal untuk mengukur motivasi belajar siswa adalah 40 pernyataan.Sebelum angket motivasi belajar ini diujikan pada kelas yang dijadikan objek 
penelitian, angket ini divalidkan kepada dosen validator ahli untuk isi dan konstruknya.Selain instrumen motivasi belajar, data dalam penelitian ini juga diperoleh dari hasil belajar ipa biologi materi sistem peredaran darah manusia dan retensi. Instrumen yang digunakan dalam pengumpulan data penelitian ini adalah soal tes hasil belajar dan retensi siswa pada ranah kognitif dalam bentuk pilihan ganda. Jumlah instrumen soal untuk mengukur hasil belajar dan retensi siswa adalah 50 soal. Kemudian dilakukan validasi untuk instrumen berbentuk tes pilihan ganda digunakan persamaan korelasi product momentdan didapatkan 25 soal valid.Untuk mengetahui realibilitas instrumen ini menggunakan rumus KR-20 dan dari hasil perhitungan, instrumen ini bersifat realibel dengan derajat relialibilitas tinggi karena memiliki nilai $r_{11}$ sebesar 0,769 . Setelah data terkumpul dilakukan perhitungan statistik untuk membuktikan ada atau tidaknya pengaruhBlended Learningberbasis Edmododan motivasi belajar terhadap hasil belajar IPA Biologi dan retensi siswa pada materi sistem peredaran darah manusia di kelas VIII SMP N 5 Medan.

\section{HASIL DAN PEMBAHASAN HASIL}

Sebelum pengujian hipotesis, terlebih dahulu dilakukan uji persyaratan analisis data.Pengujian persyaratan analisis data meliputi pengujian normalitas dan homogenitas variansi populasi. Uji normalitas data dilakukan menggunakanKolmogorov-Smirnovyang digunakan pada masing-masing kelompok perlakuan dengan menggunakan taraf signifikan $\alpha=0,05$. Dari hasil perhitungan terlihat bahwa nilai signifikanuntuk semua kelompok lebih besar daripada nilai $\alpha=0,05$. Dengan demikian dapat disimpulkan bahwa data hasil belajar, motivasi belajar dan retensi dari semua kelompok data berasal dari populasi yang berdistribusi normal.Uji homogenitas menggunakan uji Levene.Dari hasil perhitungan didapatkan data hasil belajar siswa, motivasi belajar dan retensi bersifat homogen dengan nilai signifikan $>$ 0,05 . Pengajuan hipotesis dalam penelitian ini dilakukan dengan menggunakan ANAVA dua jalur.Kemudian dilanjutkan dengan uji tuckey untuk mengetahui efek utama mana yang lebih tinggi.

Terdapat pengaruh blended learning berbasis edmodo terhadap hasil belajar IPA biologi siswa kelas VIII SMP Negeri 5 Medan (Fhitung $=86,668 ;$ P. $=0,000$ ). Hal ini dapat dilihat pada hasil belajar siswa pada materi sistem peredaran darah yang dibelajarkan dengan model pembelajaran blended learning berbasis edmodo(77,37 \pm $6,28)(\bar{X} \pm$ SD) signifikan lebih tinggi daripada yang dibelajarkan dengan model pembelajaran langsung $(58,30 \pm 10,24)$. Pengaruh Blended Learning Berbasis Edmodo terhadap Hasil Belajar IPA Biologi Siswa Kelas VIII SMP Negeri 5 Medan dapat dilihat pada Gambar 1 di bawah ini: 


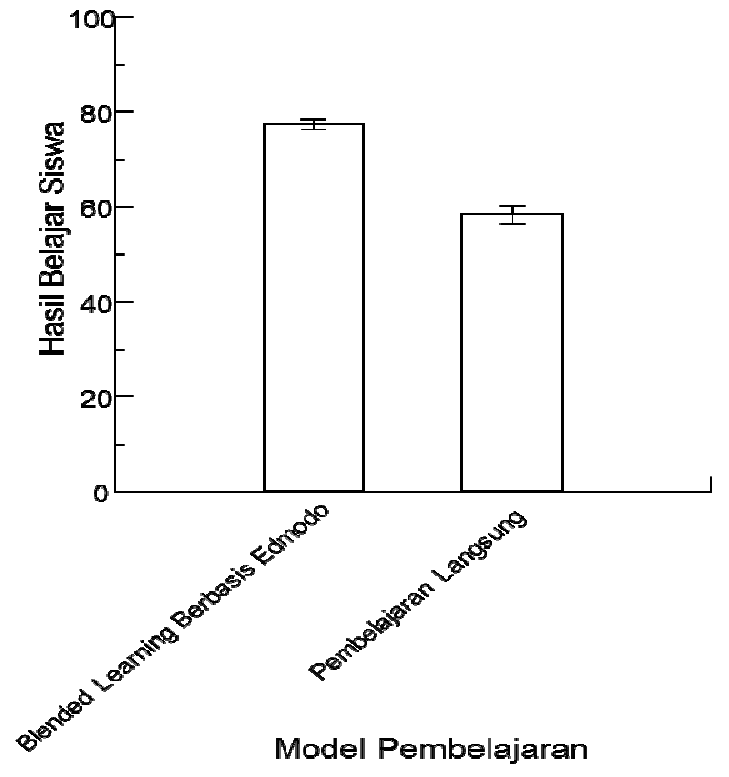

Gambar 1. Hubungan hasil belajar dengan model pembelajaran

Berdasarkan hasil uji hipotesis diperoleh terdapat pengaruh blended learning berbasis edmodo terhadap retensi belajar siswa kelas VIII SMP Negeri 5 Medan (Fhitung $=39,650 ;$ P. $=0,000)$.Hal ini dapat dilihat pada nilai retensi siswa pada materi sistem peredaran darah yang dibelajarkan dengan model pembelajaran blended learning berbasis edmodo 69,48 $\pm 12,90)(\bar{X} \pm \mathrm{SD})$ signifikan lebih tinggi daripada yang dibelajarkan denganmodel pembelajaran langsung $(50,30 \pm 13,11)$. Pengaruh Blended Learning Berbasis Edmodo terhadap Retensi Belajar Siswa Kelas VIII SMP Negeri 5 Medan tersaji pada Gambar 2 di bawah ini :

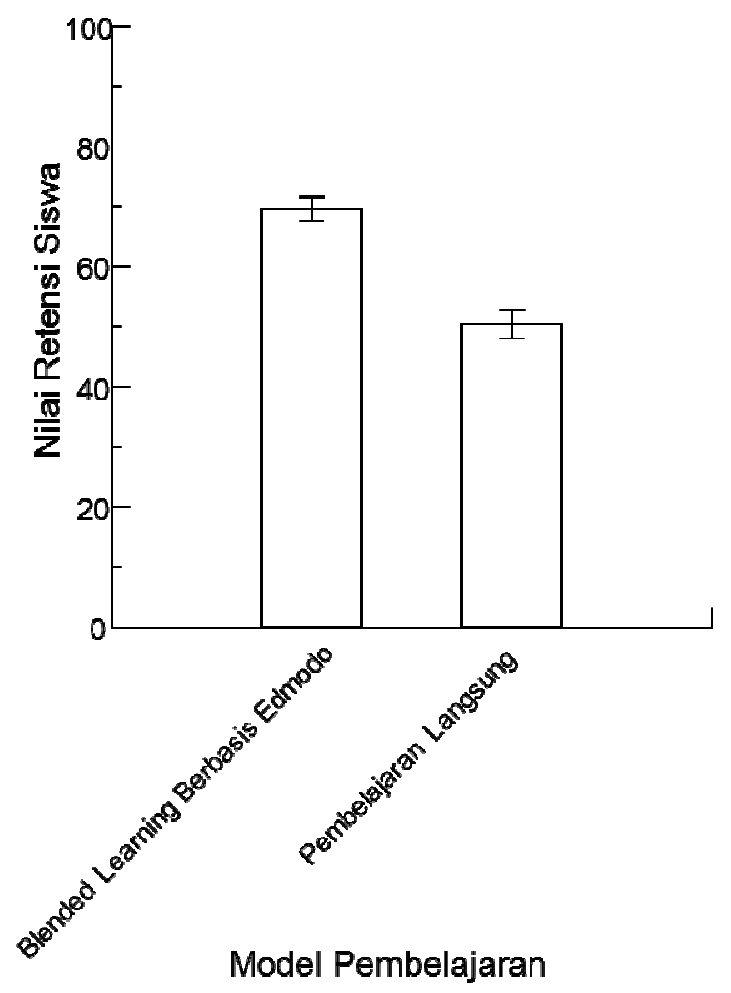

Gambar 1. Hubungan retensi belajar dengan model pembelajaran 
Terdapat pengaruh motivasi belajar terhadap hasil belajar IPA biologi siswa kelas VIII SMP Negeri 5 Medan (Fhitung = 4,913; P. = 0,030). Terdapat pengaruh motivasi belajar terhadap retensi belajar siswa kelas VIII SMP Negeri 5 Medan (Fhitung $=14,303 ;$ P. $=0,000$ ). Terdapat interaksi antara blended learning berbasis edmodo dan motivasi terhadap hasil belajar IPA biologi siswa kelas VIII SMP Negeri 5 Medan (Fhitung $=4,942 ; \mathrm{P} .=0,003$ ). Terdapat interaksi antara blended learning berbasis edmodo dan motivasi terhadap retensi belajar siswa kelas VIII SMP Negeri 5 Medan (Fhitung $=2,946 ;$ P. $=0,031$ ). Berdasarkan hasil post hoc test pada Uji Tukey diperoleh bahwaterdapat perbedaan yang signifikan hasil belajar IPA biologi siswa yang diajar dengan model blended learning berbasis edmodo yang memiliki motivasi tinggi dengan hasil belajar IPA biologi siswa yang diajar dengan model blended learning berbasis edmodo yang memiliki motivasi rendah $(\mathrm{P} .=0,016)$, Dengan hasil belajar IPA biologi siswa yang diajar dengan model pembelajaran langsung yang memiliki motivasi tinggi $(\mathrm{P} .=0,000)$. Dengan model pembelajaran langsung yang memiliki motivasi rendah $(\mathrm{A} 2 \mathrm{~B} 2 \mathrm{Y} 1) \quad(\mathrm{P} .=0,000)$. Tidak terdapat perbedaan yang signifikan hasil belajar biologi siswa yang diajar dengan model blended learning berbasis edmodo yang memiliki motivasi rendah dengan hasil belajar IPA biologi siswa yang diajar dengan model pembelajaran langsung yang memiliki motivasi tinggi $(\mathrm{P}=0,368)$, dengan hasil belajar IPA biologi siswa yang diajar dengan model pembelajaran langsung yang memiliki motivasi rendah (A2B2Y1) $(\mathrm{P} .=0,066)$.

Berdasarkan hasil post hoc test pada Uji Tukey diperoleh bahwatidak terdapat perbedaan yang signifikan nilai retensi siswa yang diajar dengan model blended learning berbasis edmodo yang memiliki motivasi tinggi dengan nilai retensi siswa yang diajar dengan model blended learning berbasis edmodo yang memiliki motivasi rendah $(\mathrm{P} .=0,582)$, terdapat perbedaan yang signifikan nilai retensi siswa yang diajar dengan model blended learning berbasis edmodo yang memiliki motivasi tinggi dengan nilai retensi siswa yang diajar dengan model pembelajaran langsung yang memiliki motivasi tinggi $(\mathrm{P} .=0,000)$, dengan nilai retensi siswa yang diajar dengan model pembelajaran langsung yang memiliki motivasi rendah (P. $=0,001)$. Tidak terdapat perbedaan yang signifikan nilai retensi siswa yang diajar dengan model blended learning berbasis edmodo yang memiliki motivasi rendah dengan nilai retensi siswa yang diajar dengan model pembelajaran langsung yang memiliki motivasi tinggi $(\mathrm{P}=0,371)$, dengan nilai retensi siswa yang diajar dengan model pembelajaran langsung yang memiliki motivasi rendah $(\mathrm{A} 2 \mathrm{~B} 2 \mathrm{Y} 2)(\mathrm{P} .=0,184)$.

\section{PEMBAHASAN}

Pada hasil penelitian ini diperoleh bahwahasil belajar siswa pada materi sistem peredaran darah yang dibelajarkan dengan model pembelajaran blended learning berbasis edmodo $(77,37 \pm 6,28) \quad(\bar{X}$ \pm SD)signifikan lebih tinggi daripada yang dibelajarkan dengan model pembelajaran langsung $(58,30 \pm 10,24)$ sebesar 19,07\%. Hal ini disebabkan karenablended learning merupakan proses pembelajaran yang dilakukan dengan bantuan media elektronik atau proses pembelajaran yang dapat berlangsung secara online. Dimana dalam blended learning diperoleh satu kesatuan yang menggabungkan materi pembelajaran IPA biologi dalam proses pembelajaran tatap muka secara online. Oleh sebab itu proses pembelajaran blended learning ini sangat sesuai dengan kebutuhan pada siswa sekarang yang melaksanakan proses pembelajaran secara menarik dengan bantuan teknologi multimedia melalui internet, dimana media internet pada saat ini sangat erat kaitannya terhadap aktivitas siswa dalam memperoleh informasi pengetahuan khususnya pada materi pembelajaran IPA biologi. Hal ini dapat memberikan dampak terhadap hasil yang lebih baik secara optimal pada hasil belajar siswa.Hasil penelitian ini didukung oleh Yuniar (2014) bahwa "terdapat peningkatan hasil belajar siswa yang menggunakan edmodo pada pembelajaran dengan 
modelblended learning dibandingkan dengan hasil belajar siswa yang menggunakan pembelajaran dengan metode konvensional".

Pada hasil penelitian ini diperoleh bahwa nilai retensi siswa pada materi sistem peredaran darah yang dibelajarkan dengan model pembelajaran blended learning berbasis edmodo $(69,48 \pm 12,90)$ ( $\bar{X} \pm$ SD)signifikan lebih tinggi daripada yang dibelajarkan dengan model pembelajaran langsung $(50,30 \pm 13,11)$ sebesar 19,18\%. Hal ini disebabkan karena model pembelajaran blended learning berbasis edmodo merupakan proses pembelajaran yang membagikan materi dan konten pendidikan baik secara online maupun offline. Dengan konten-konten pendidikan seperti materi pelajaran IPA biologi maka dapat memberikan keinginan siswa untuk selalu mau belajar dengan frekuensi karena mudahnya mengakses edmodo ini.Umaroh (2012) menyatakan bahwa "kelebihan edmodo diantaranya adalah membuat pembelajaran tidak bergantung pada waktu dan tempat dan membuat kelas lebih dinamis karena memungkinkan interaksi guru dengan siswa maupun antara siswa dengan siswa dalam hal pelajaran atau tugas".Frekuensi siswa yang selalu mengakses edmodo dapat memberikan ingatan yang bertahan panjang karena siswa dapat dengan mudah mengingat dan memahami materi IPA biologi melalui sistem informasi berbasis jejaring sosial ini.

Pada hasil penelitian ini diperoleh hasil belajar berdasarkan tingkat motivasi belajar siswa pada materi peredaran darahyang dibelajarkan dengan model pembelajaran blended learning berbasis edmodo, yaitu: (1) yang memiliki motivasi tinggi sebesar $78,83 \pm 4,75 \quad(\bar{X} \pm \mathrm{SD})$; dan (2) yang memiliki motivasi rendah sebesar 66,00 \pm 5,16.Sedangkan hasil belajar berdasarkan tingkat motivasi belajar siswa pada materi peredaran darahyang dibelajarkan dengan model pembelajaran langsung (1) yang memiliki motivasi tinggi sebesar 59,17士 9,93 ; dan (2) yang memiliki motivasi rendah sebesar 52,00 \pm 11,77. Hasil penelitian ini memberikan gambaran bahwa hasil belajar siswa yang menggunakan model pembelajaran blended learning berbasis edmodo memiliki hasil belajar yang lebih baik dibanding dengan pembelajaran langsung (konvensional). Hal ini disebabkan karena pada proses pembelajaran blended learning berbasis edmodoini siswa menjadi tertarik, karena terdapat kemudahan bentuk interaksi guru dengan siswa dalam berkomunikasi dan berkolaborasi dalam berbagai kemudahan konten berupa teks, gambar, links, video, maupun audio.Sebagaimana hasil penelitian Herliana (2015) yang menyimpulkan bahwa "terdapat interaksi antara model pembelajaran blended learning dan motivasi belajar terhadap hasil belajar siswa di sekolah". Siswa yang memiliki motivasi belajar tinggi maka hasil belajar siswa dengan model Blended learning lebih tinggi dibandingkan pembelajaran langsung.

Pada hasil penelitian ini diperoleh nilai retensiberdasarkan tingkat motivasi belajar siswa pada materi peredaran darahyang dibelajarkan dengan model pembelajaran blended learning berbasis edmodo, yaitu: (1) yang memiliki motivasi tinggi sebesar $70,45 \pm 11,85(\bar{X} \pm$ SD); dan (2) yang memiliki motivasi rendah sebesar 62,00 \pm 12,00.Sedangkan nilai retensiberdasarkan tingkat motivasi belajar siswa pada materi peredaran darahyang dibelajarkan dengan model pembelajaran langsung (1) yang

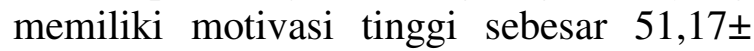
$13,49)$; dan (2) yang memiliki motivasi rendah sebesar 44,00 \pm 8,64. Hasil penelitian ini memberikan gambaran bahwa nilai retensisiswa yang menggunakan model pembelajaran blended learning berbasis edmodo memiliki nilai retensiyang lebih baik dibanding dengan pembelajaran langsung (konvensional). Hal ini disebabkan karena model pembelajaran blended learning berbasis edmodo merupakan proses pembelajaran yang berlangsung tatap muka secara online, sehingga menjadi pengalaman belajar yang unik bagi para siswa. melalui penyajian pembelajaran blended learning berbasis edmodo, maka retensi daya ingat siswa pada materi pembelajaran IPA biologi dapat 
terlatih dan membantu para siswa dalam mengenali dan mengingat.Edmodo mudah diakses oleh siswa sehingga memberikan dampak pengaruh terhadap pengalaman belajar siswa kedalam pembelajaran bermakna bagi siswa. Karena pembelajaran yang melibatkan panca indra dalam proses berfikir dapat memungkinkan pembelajaran lebih bermakna, sehingga demikian memungkinkan kuatnya retensi siswa terhadap konsep-konsep IPA biologi yang diajarkan oleh guru kepada para siswa.Hal ini sejalan dengan penemuan Usta dalam Korkmaz (2009) yang menyatakan bahwa "blended learning berkontribusi lebih untuk prestasi akademik dan retensi jika dibandingkan dengan pembelajaran online".

\section{SIMPULAN}

Berdasarkan hasil penelitian dan analisis data, maka dapat diambil simpulan sebagai berikut: (1) Terdapat pengaruh blended learning berbasis edmodo terhadap hasil belajar IPA biologi siswa kelas VIII SMP Negeri 5 Medan.(2) Terdapat pengaruh blended learning berbasis edmodo terhadap retensi belajar siswa kelas VIII SMP Negeri 5 Medan. (3) Terdapat pengaruh motivasi belajar terhadap hasil belajar IPA biologi siswa kelas VIII SMP Negeri 5 Medan. (4) Terdapat pengaruh motivasi belajar terhadap retensi belajar siswa kelas VIII SMP Negeri 5 Medan. (5) Terdapat interaksi antara blended learning berbasis edmodo dan motivasi terhadap hasil belajar IPA biologi siswa kelas VIII SMP Negeri 5 Medan. (6) Terdapat interaksi antara blended learning berbasis edmodo dan motivasi terhadap retensi belajar siswa kelas VIII SMP Negeri 5 Medan.

\section{DAFTAR PUSTAKA}

Herliana, F. 2015. Pengaruh Model Pembelajaran Berbasis Blended learning dan Motivasi Belajar terhadap Hasil Belajar Fisika Siswa SMA.Prosiding Seminar Nasional Fisika, (E-Journal), Vol. IV, (http : //snf-unj.ac.id/kumpulan-prosiding/snf2015/, diakses 4 November 2015).

Korkmaz, Ozgen \& Karakus, Ufuk. 2009. The Impact of Blended Learning Model on Student Attitudes Towards Geography Course and Their Critical Thinking Dispositions and Levels. The Turkish Online Journal of Educational Technology.ISSN : 1303-6521. Vol 8, Issue 4, Article 5.

Umaroh, S. 2012. Penerapan Project Based Learning Menggunakan Microblogging Edmodo Untuk Meningkatkan Prestasi Belajar Siswa Pada Mata Pelajaran TIK. Skripsi tidak diterbitkan. Jakarta: Universitas Pendidikan Indonesia.

Yuniar, L, E. 2014. Penerapan Metode Blended learning untuk Meningkatkan Hasil Belajar Siswa pada Pembelajaran Sejarah.Jakarta : Universitas Pendidikan Indonesia.

Zwang, J. 2010. Edmodo:A Free, Secure, Social Networking Site For School. (Online), (http://www.eschoolnews.com/2010/12/15/e dmodo-a-free-secure-social-networking-sitefor-school/, diakses 20 September 2015). 